\title{
Bioactive Components of Milk Fat Globule Membrane and Technological Applications
}

\author{
Tulay Ozcan (Corresponding author) \\ Bursa Uludag University, Faculty of Agriculture, \\ Department of Food Engineering, Bursa-Turkey \\ E-mail: tulayozcan@uludag.edu.tr \\ Merve Demiray-Teymuroglu \\ Bursa Uludag University, Faculty of Agriculture, \\ Department of Food Engineering, Bursa-Turkey \\ E-mail: 501908004@ogr.uludag.edu.tr
}

\begin{abstract}
The membrane contained in milk and surrounding the milk fat spheres represents a nutraceutical matrix in a unique biophysical system called the milk fat globule membrane or membrane (MFGM). In recent years, the identification of the various health-beneficial components of MFGM has been evaluated as a food ingredient with bioactive properties, while increasing the interest in the development of functional products as well as efforts to improve the technological properties of foods. MFGM switches to buttermilk during butter production. Buttermilk is rich in phospholipid and bioactive peptide content and draws attention with its emulsification effect in foods. In addition, MFGM compounds also have an anticarcinogenic, antibacterial, blood pressure and cholesterol-lowering effect, anti-oxidative stress and cardiovascular discomfort, as well as regulating the immune system. With its stated positive effects, this membrane material enables the development of new nutraceutical foods.
\end{abstract}

Keywords: Milk Fat Gobule Membrane, Bioactive Component, Nutraceutical, Buttermilk.

DOI: $10.7176 / \mathrm{JSTR} / 6-08-02$

\section{Süt Yağı Gobül Membranının Biyoaktif Bileşenleri ve Teknolojik Uygulamaları}

\begin{abstract}
Özet
Sütte bulunan ve süt yağı küreciklerini çevreleyen zar, süt yağı globül membranı (MFGM) ya da zarı olarak adlandırılan, benzersiz bir biyofizik sistemde nutrasötik bir matriksi temsil etmektedir. Son yıllarda, MFGM'nin sağlığa yararlı çok çeşitli bileşenlerinin tanımlanması, biyoaktif özellikleri bulunan bir gıda bileşeni olarak değerlendirilmesini sağlarken, fonksiyonel ürünlerinin geliştirilmesine olan ilginin ve ayrıca gıdaların teknolojik özelliklerinin iyileştirilmesine yönelik çalışmaların artmasına neden olmuştur. MFGM, tereyağı üretimi sırasında yayıklaltı suyuna geçmektedir. Yayıkaltı suyu fosfolipid ve biyoaktif peptid içeriği yönünden zengin olup gıdalarda emülsifikasyon etkisi ile dikkat çekmektedir. Ayrıca, MFGM bileşiklerinin anti-kanserojen, anti-bakteriyel, kan basınc1 ve kolesterol düşürücü, antioksidatif stres ve kalp- damar rahatsılıklarını azaltıcı etkisi ile ayrıca bağışıklık sistemini düzenleyici özelliği de bulunmaktadır. Belirtilen olumlu etkileri ile bu membran materyali yeni nutrasötik gıdaların geliştirilmesine olanak sağlamaktadır.
\end{abstract}

Anahtar Kelimeler: Süt Yağı Gobül Membranı, Biyoaktif Bileşen, Nutrasötik, Yayıkaltı Suyu

\section{Giriş}

Son yıllarda, besleyici özelliklerinin yanında tedavi edici, metabolik fonksiyonları ve sağlıklı olma halini geliştirici etkileri bulunan fonksiyonel bileşenlere sahip gıdalara olan tüketici talepleri artmakta ve tüketim ile biyolojik işlevsellik sağlayabilen gıda matrikslerinin tasarımıyla ilgili yenilikçi yaklaşımlar da giderek yaygınlaşmaktadır. Nutrasötik bileşenleri içeren gıdaların kalp-damar rahatsızlıkları, 
hipertansiyon, kanser, diyabet, ülser, kolestrol gibi hastalıkların oluşumunu önlediği ve metabolik şartlarda iyileşme gösterdiği çalışmalar sonucunda kanıtlanmıştır (Birch ve Bonwick, 2019).

Dünya genelindeki fonksiyonel gıda pazarı göz önüne alındığında süt ve süt ürünlerinin payı yüksektir ve bu bağlamda sütün içeriğinin terapötik ve biyoaktif bileşen olarak potansiyel kullanımını daha iyi değerlendirmek için çok sayıda çalışma yapılmaktadır. Esas olarak yağ, protein, laktoz, vitamin ve minerallerden oluşan süt ürünleri nutrasötik bileşenlerin taşınması için en uygun besin gruplarındandır (Karaman ve Özcan, 2018).

Süt yağı, yoğurt, tereyağı, peynir ve dondurma gibi pek çok süt ürününün teknolojik işlevselliğini, tekstürünü, duyusal özelliklerini ve besin profilini belirlemede ana unsurlardan birisi olarak ortaya çıkmaktadır (Truong ve ark. 2016). Süt lipitleri, inek sütünde doğal olarak emülsifiye edilmiş globüllerin (0,1-20 $\mu \mathrm{m}$ çapında) kolloidal süspansiyonları içinde bulunmaktadır ve her bir globül, üç katmanlı bir globül zarı ile sarılmış bir triaçilgliserol (TAG) çekirdeğini içermektedir (Lopez ve ark. 2011). Sütteki doğal süt yağı globüllerinin (MFG) büyüklüğü, bileşimi, yapısı ve salgılanmasının kontrolü, meme bezlerinin hücresel regülasyon sistemi tarafindan düzenlenmektedir (Heid ve Keenan, 2005).

Sütteki yağ globülleri basit bir su içinde yağ emülsiyonu değildir; globüller, yüzey aktif materyalin basit bir mono-moleküler filmi olarak düşünülemeyen karmaşık bir zar ile çevrilidir. Bu zar, meme salg1 hücresindeki sentez sırasında ortaya çıkan birkaç farklı katmana sahiptir ve genellikle süt yağı globül zar1 (MFGM) olarak adlandırılmaktadır. Yağ emülsiyonunun stabilitesi, yağ globüllerini çevreleyen ve serbestçe birleşmesini önleyen süt yağı globül zarı mebranından (MFGM) etkilenmektedir. MFGM'nin bir proteomik çalışması, sığır MFGM bileşiminin \%69-73 lipit ve \%22-24 protein içerdiğini ortaya koymaktadır. MFGM'nin protein içeriği, toplam süt proteininin \%1-4'ünü oluşturmakla birlikte, biyoaktif proteinleri yüksek oranda içermektedir (Cavaletto ve ark. 2008; Lopez, 2011).

Süt yağı globülleri, çoklu bir boyut dağılımına sahiptir ve bu çoklu dağılım, türler arasında korunmakta ve biyolojik önem taşımaktadır (Michalski ve ark. 2005a). Globülün boyutu ne kadar küçük olursa, bağırsaktaki diğer moleküller veya mikroorganizmalarla etkileşimler için kullanılabilecek yüzey alanı o kadar büyük olmaktadır. İnsan sütündeki süt yağı globülleri üzerine yapılan bir çalışma, büyük süt yağ1 globüllerine ek olarak, laktozomlar adı verilen protein ve lipitlerden oluşan ortalama $25 \mathrm{~nm}$ çapında büyük bir nanokürecik popülasyonunun olduğunu göstermektdir (Argov ve ark. 2008 ). Büyük süt yağ1 globüllerinin aksine, laktozomlar önemli bir trigliserit çekirdek içermezler ve enerji kaynağı değildirler. Aksine bunların yüzey bileşenlerinin önemli biyolojik işlevselliğe sahip olduğu, örneğin immünomodülatör fonksiyonlar gösterdiği düşünülmektedir. Bu doğal nano yapılar üzerindeki lipitomik ve proteomik analizler, süt yağı globüllerinden farklı bir salgılayıcı veya biyosentetik yoldan üretidiğini göstermektedir (Argov-Argaman ve ark. 2010).

Sığır sütünde emülsiyon yapıda ve çok küçük damlacıklar veya globuller şeklinde dağılmış olarak yaklaşık \%3-5 yağ bulunmaktadır. Globüller negatif yüke sahip olup, taze sütte zeta potansiyeli - $12 \mathrm{mV}$ olarak belirtilmektedir. Yağ kürecik boyutu, inek türü, emzirme aşaması ve sağım gibi özelliklere bağlı bulunmaktadır. Örneğin, Jersey ineklerinin sütünden gelen yağ globülleri (ortalama boyut yaklaşık 4.5 $\mu \mathrm{m})$ Holstein rk ineklerin sütünden gelen yağ globüllerinden daha büyüktür (ortalama boyut yaklaşık $3.5 \mu \mathrm{m})$. Aynı ırklar arasında da farklılıklar gözlenebilmektedir. Ayrıca laktasyon ilerledikçe ortalama yağ globül boyutunda da bir azalma olmaktadır (Singh, 2006).

MFGM biyolojik bir zar olup, proteinler, fosfolipidler, glikoproteinler, enzimler ve diğer küçük bileşenlerden oluşmaktadır. Meme bezinin salgı hücrelerinde oluşan yağ globülleri; endoplazmik retikulum zarın içinde veya üzerinde sentezlenerek sitoplazmada mikro-lipit damlacıkları şeklinde birikmektedir. MFGM'nin bileşimi, yağ içeriği, yağ kürecik boyutu, diyet, cins, sağlik ve ineklerin emzirme aşaması gibi birçok faktöre bağlı olarak büyük ölçüde değişebilmektedir (Singh, 2006; Vanderghem ve ark. 2010). Bu hücre içi damlacıklar, fosfolipidler, glikosfingolipidler, kolesterol, nötrlipitler ve proteinlerden oluşan yaygın bir arayüzey tabakasıyla kaplıdır._Mikro-lipit damlacıkları, çeşitli boyutlarda sitoplazmik lipit damlacıklarını oluşturmak için birbirleriyle kaynaşarak hacim olarak büyümekte; bunlar daha sonra bilinmeyen mekanizmalar ile sitoplazma yoluyla hücrenin apikal kutbuna taşınarak epitelyal hücreden salgılanmaktadır. Salgılama sırasında, damlacıklar dış plazma zarı ile kaplanarak hücreden ayrılmaktadır. Yağ küreciklerini çevreleyen zarın bileşimi, salgı hücrelerinin apikal plazma zarının yapısına benzemektedir. Salgılanmayı takiben, globülleri çevreleyen zarın bir kısmı yağsız süte geçebilmektedir (Danthine ve ark. 2000; Singh, 2006).

MFGM, doğal bir emülsifiye edici ajan olarak işlev görmekte, sütte yağ globüllerinin topaklanmasını ve birleşmesini önlemekte ve yağı enzim etkisine karşı korumaktadır. MFGM, 1sıtma, soğutma, homojenizasyon, buharlaşma ve sprey kurutma gibi süt işleme işlemlerinden belirgin şekilde etkilenmektedir. Sonuç olarak da, süt ürünlerinin birçok özelliği de bu fonksiyonel membran sisteminden doğrudan etkilenmektedir (Walstra, 1995; Evers, 2004). Son yıllarda, gıda ve gıda dışı uygulamalarda bir bileşen olarak MFGM'nin potansiyel kullanımlarının araştırılmasına yönelik ilgi artmaktadır. MFGM

11 | P a g e 
proteinlerinin ve MFGM lipidlerinin nutrasötik özelliklere ve sağlı yararlarına sahip olduğu belirlenmiştir (Singh, 2006).

\section{Süt Yağı Globül Membranının Bileşimi ve Yapısı}

MFGM'nin bileşimi hakkındaki bilgiler, izolasyon ve saflaştırma için uygulanan farklı yöntemler nedeniyle oldukça değişkenlik göstermektedir. Lazer konfokal tarama mikroskobu ile belirlenen mikrograflar ile de MFGM'nin yapısı ve lateral organizasyonu tanımlanabilmektedir (Contarini ve Povolo, 2013).

Süt, esas olarak yăg globülleri içeren doğal bir su içinde yağ emülsiyonudur. Burada MFGM, sulu fazdaki süt yağının yapısal bütünlüğünün korunmasını ve stabilitesini sağlamaktadır (Danthine ve ark. 2000; Ye ve ark. 2002). Yağ globülleri, doğal bir emülgatör olarak işlev gören ve polar olmayan trigliserit çekirdeğini kapsülleyen MFGM tarafından enzimatik bozulma ve birleşmelerden korunmakta ve trigliseritlerin stabil dağılımını sağlamaktadır. Membranda bulunan polar lipidler, proteinler, glikoproteinler, elektrostatik ve sterik itmeye neden olarak yağ globüllerinin birleşmesini ve birikmesini önlemektedir (Lopez, 2011; Arranz ve Correding, 2017).

MFGM' yapısı Danthine ve ark. (2000) ve Evers (2004)'in belirttiği modellerden esinlenerek oluşturulmuştur (Şekil 1) MFGM, 10- 50 nm kalınlığında üç katmanlı bir yapıdan oluşmaktadır: i) yăg damlacığının etrafını kuşatan, polar lipidler ve proteinlerden oluşan tek katlı "iç tabaka", ii) en dışta yer alan, polar lipidler ve proteinlerden oluşan çift katmanlı "gerçek membran", iii) çift katmanlı gerçek membranın iç yüzü ile tek katlı iç tabaka arasında yer alan "elektron yoğun proteinimsi kılıf”. Yağ damlacığının etrafını saran tek katlı iç tabaka granüllü endoplazmik retikulum tarafından üretilmektedir. Bu tek tabakada, polar lipidlerin hidrofobik kuyrukları trigliserit bakımından zengin çekirdek ile temas halindedir. Kolesterol polar lipid tabakasında yer almaktadır. İç ve dış membran (gerçek membran) arasında yer alan proteinimsi kılıfın (10-50 nm kalınlığında) muhtemelen salg1 hücrelerinde, yağ damlacığının granüllü endoplazmik retikulumdan hücrenin apeks bölgesine taşınması aşamasında oluştuğu ileri sürülmektedir. Kutupsal lipitlerin en diştaki hidrofilik grupları sütün sulu fazıyla temas halinde olduğu salgı hücresi apikal plazma zarından kaynaklanan bir dış çift katman yapıdadır. Bu çift katman, iç yüzünde elektron yoğun bir kaplama malzemesine sahip iken, bazı globüller, globüller ve çevresindeki membran arasında sürüklenen 'sitoplazmik hilal' olarak adlandırılan yapılar da bulundurmaktadır (Danthine ve ark. 2000; Keenan ve Mather, 2006).
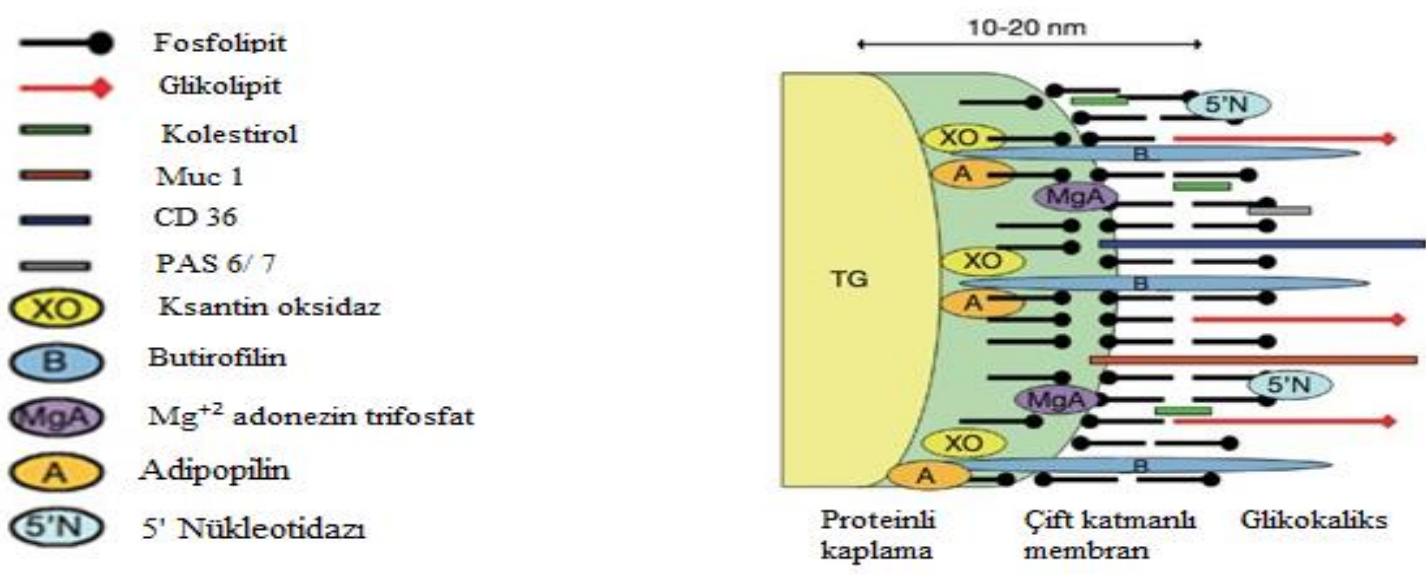

Şekil 1. Süt yağı globül membranın yapısı (Danthine ve ark. 2000; Evers, 2004; Michalski ve ark. 2005b)

Yoğun protein tabakası (10-50 nm kalınlığında) ve karmaşık moleküler yapısı ile MFGM, gerçek bir biyolojik zar olarak kabul edilmekte ve krema yayıklama (süt yağı globüllerinin dengesizleştirilmesi) sırasında ise sulu faza ayrılmaktadır (Vanderghem ve ark. 2010). Bu anlamda süt ürünleri içerisinde MFGM'ı en yüksek konsantrasyonlarda içeren tereyağı üretimden arta kalan yayıkaltı suyudur (Dewettinck ve ark. 2008; Vanderghem ve ark. 2010). Bu yayıkaltı fraksiyonu ayrıca yağsız sütten elde edilen önemli miktarda proteini de içermektedir. Buradan, kazeinleri ayırmak ve MFGM'nin yayıkaltı suyundan fraksiyonlaşmasını sağlamak için sodyum sitrat kullanılabilmektedir (Corredig ve ark. 2003). MFGM'nin yayıkaltından ekstraksiyonu için diğer alternatifler arasında, ultrafiltrasyon (UF) ve ardından özellikle fosfolipidlerle zenginleştirilmiş bir bileşen elde etmek için süperkritik sıvı ekstraksiyonu yöntemi kullanılmasıdır (Costa ve ark. 2010).

12 | P a g e

www.iiste.org 
MFG'nin aslında temel fizyolojik rolü emzirilen buzağıya beslenme, özellikle enerji ve biyoaktif moleküller sağlamasıdır. Ortalaması $4 \mu \mathrm{m}$ olan MFGM'nin çapı, 0.1-15 $\mu \mathrm{m}$ arasında değişmektedir. Laktasyonun aşamalarına bağlı olarak, türler ve mevsimler arasındaki değişiklikler MFG'nin büyüklüğünü ve büyüklük dağılımını farklılaştırmaktadır (Logan ve ark. 2014). Belirtilen faktörlere bağlı olarak da MFGM'nin bileşimi geniş ölçüde değişebilmekte, yağ içeriği, buna bağlı olarak globül büyüklüğ̈ü, diyet, cins, sağllk ve ineklerin emzirme evresi etkili olmaktadır (Singh, 2006; Vanderghem ve ark. 2010). Ek olarak, sağım, yaşlılık durumu, hava ve sıcaklık değişiklikleri ve 1sıl işlemler gibi süt işleme prosedürleri de MFGM'nin bileşimini etkileyebimektedir. Bu sebeple, toplam yağ globül kütlesi kesin olarak belirlenememiştir. Membranın tahmini kütlesi, toplam yăg globüllerinin kütlesinin \% 26'sıdır. Proteinler ve fosfolipidler birlikte membran kuru ağırlığının \%90'ından fazlasını oluşturmakta, ancak lipitlerin ve proteinlerin nispi oranları büyük ölçüde değişebilmektedir (Keenan ve Dylewski, 1995; Keenan, 2001; Singh, 2006).

MFGM'nin ana bileşenleri karmaşık bir bileşime sahip polar lipidlerdir. Polar lipidler, toplam süt lipitlerinin sadece \%0.1-2'sini içerdiği için sütün minör bileşenleri olarak kabul edilmektedir. Polar süt lipitlerinin fonksiyonel bileşen olarak kullanımı, tüketime bağlı beslenme ve sağlık yararlarına dair artan sonuçlar nedeniyle son y1llarda dikkat çekmektedir (Singh, 2006; Månsson, 2008). MFGM, polar lipidlerden gliserofosfolipidler, fosfatidilkolin (PC, toplam polar lipidlerin \%3536's1), fosfatidiletanolamin (PE , \%27-30), fosfatidilinositol (PI , \%5-11) ve sfingolipidlerdan esas olarak, sfingomiyelin (SM, \%25) den oluşmaktadır (Lopez ve ark. 2008; Lopez, 2011; Arranz ve Corredig, 2017). Ayrıca, yağ kürecik boyutu da polar lipid bileşimini etkilemektedir. Ortalama çap1 $2 \mu \mathrm{m}$ olan yağ küreciklerinde PI daha yüksek konsantrasyonda bulunurken, ortalama çapı $3 \mu \mathrm{m}$ olan küreciklerde PE konsantrasyonu daha yüksektir, PC konsantrasyonu ise yağ kürecik boyutuna göre etkilenmemektedir (Mesilati-Stahy ve ark. 2011; Arranz ve Corredig, 2017). Sütteki polar lipidlerin konsantrasyonu ile ilgili olarak bir çalışma, inek sütünde manda sütünden $\% 28$ daha yüksek bir içerik olduğunu belirtmektedir. Bu farkın, inek sütündeki yağ globüllerinin daha küçük boyut dağılımı ve sonuç olarak da, manda sütüne kıyasla daha büyük yüzey alanlarıyla ilişkili olduğu belirtilmiştir (Ménard ve ark. 2010).

Bazı çalışmalar, MFGM'nin dış iki tabakasındaki, hücre zarlarını Singer ve Nicolson (1972)’ın sıvı mozaik modeline karşılık gelen rastgele bir polar lipid organizasyonu olarak tarif etmektedir (Michalski ve ark. 2005b; Dewettinck ve ark. 2008). Bununla birlikte, mikroskopik görüntüleme tekniklerinin uygulanması, fosfolipidlerin lateral organizasyonunun detaylı tanımlanmasına yol açarak, MFGM'deki lipitlerin ve proteinlerin heterojen dağılımını vurgulanmaktadır (Gallier ve ark. 2010b).

MFGM, yarısından fazlası hidrolaz sınıfına dahil en az 25 farklı enzim içermektedir, bunu oksidoredüktazlar ve transferazlar takip etmektedir. Bunlar içinde, en çok bulunan enzimler ise, alkalin fosfataz ve ksantin oksidazdır (Keenan, 2001; Singh, 2006). Yayıkaltından izole edilen fraksiyonların, su içinde yağ emülsiyonlarını stabilize etmek için fonksiyonel bir bileşen olarak kullanım etkisi izolasyon tekniğine göre değişmektedir (Snow ve ark. 2010, 2011; Zanabria ve ark. 2014a,b; Arranz ve Corredig, 2017).

Nötr lipitler, MFGM'deki toplam lipitlerin \%56-80'ini oluşturmaktadır. Trigliseritler nötr lipitlerin ana fraksiyonlarından biri olup toplam lipitlerin \%37-68'i şeklindedir. Bu trigliseritlerin büyük bir kısmının, MFGM'nin izolasyonu sırasında lipit çekirdeği tarafından kontaminasyondan kaynaklandığ belirlenmiştir. Diğer nötr lipitler: digliseritler (\%9), monogliseritler (\%0.7), esterler (\%0.1-0.8) ve kolesterol (\%0.2-6.1) şeklinde toplam lipitlerin\% 'si olarak sınıflandırılabilmektedir (Danthine ve ark. 2000). Fauquant ve ark. (2007) yaptığ 1 bir çalışmada. kütle spektrometresi yaklaşımıyla birleştirilmiş bir gaz kromatografisi kullanılarak, MFGM'de lanosterol, lathosterol, desmosterol, stigmasterol ve $\beta$ sitosterol gibi birçok küçük biyoaktif sterol saptamışlardır (Vanderghem ve ark. 2010).

MFGM fosfolipidleri, palmitik (16: 0), stearik (18: 0) ve tricosanoic (23: 0) gibi yüksek miktarlarda uzun zincirli yă̆ asitleri içerirken, kısa ve orta zincirli yağ ise asitleri çok ise düşük oranlarda bulunmaktadır. MFGM, iki majör nötr glikosfingolipid, glukozilseramid (\%35) ve laktosilseramid (\%65) içermektedir. Gangliosidler, bir seramid ve bir veya daha fazla siyalik aside ve birkaç şekere bağlı bir oligosakkarit zincirinden oluşan glikosfingolipidlerdir. Gangliosidlerin miktarı yaklaşık $8 \mu \mathrm{g} / \mathrm{mg}$ membran proteinidir ve bileşiminin, meme bezindeki salgı hücrelerinin apikal plazma membranlarınınki ile aynı olduğu belirtilmektedir (Jensen ve Newberg, 1995; Singh, 2006).

Gliserofosfolipidler ve sfingolipidler, kantitatif olarak sütteki en önemli fosfolipidlerdir (PL). Süt yağ1 globül zarında (MFGM) ve yağsız süt fazının diğer membranöz materyalinde bulunmaktadırlar. Bunlar genellikle fosfatidilkolin, fosfatidiletanolamin, fosfatidilinositol ve fosfatidilserin içerirken, sfingomiyelin sfingolipidlerin baskın türleridir. Polar lipidler sütte sudaki yağın emülsifikasyonu için temeldir, çünkü proteinlerle birlikte, meme bezi hücreleri tarafından salgılanan lipit damlacıklarını çevreleyen süt yağ 1 globül zarının (MFGM) ana bileşenleridir (Contarini ve Povolo, 2013).

13 | P a g e

www.iiste.org 
Gliserofosfolipidler, gliserol, fosforik asit, yağ asitleri ve bir hidroksi bileșiğinden (örn., Kolin, etanolamin, serin, inositol) oluşmaktadır. Şekil 2, süt yağında bulunan önemli PL'lerinin (fosfatidilkolin (PC), fosfatidiletanolamin (PE), fosfatidilinositol (PI) ve fosfatidilserin (PS) yapısın göstermektedir. Esas olarak doymamış yağ asitleri (FA's) ile temsil edilen iki yă̆ asidi, gliserol omurgasının $s n-1$ ve $s 2$ pozisyonlarında esterleşmektedir (Contarini ve Povolo, 2013).

Süt sphingomyelinin (SM) yağ asidi bileşimi tamamen farklı olup, temel yağ asitleri, C16: 0, C18: 0, C18: 1n9, C22: 0, C23: 0 ve C24: 0 șeklindedir, bu nedenle oldukça doymuş bir özelliğe sahiptir (Fong ve ark. 2007; Graves ve ark. 2007; Gallier ve ark. 2010a). PL'nin bileşimi Çizelge 1'de verilmektedir. Toplam polar lipit içeriği miktarı 0.25 ila $0.96 \mathrm{~g} / 100 \mathrm{~g}$ yağ arasında değişmektedir. Bu değişkenlik ekstraksiyon ve analiz yöntemlerindeki farklılıkların yanı sıra hayvanın diyeti ve emzirme dönemi gibi diğer faktörlerle de açıklanabilir. Toplam PL'lerin yüzdesi olarak ifade edilen süt yağındaki en çok bulunanl PL'ler, PE (toplam PL'nin\% 26.4-72.3'ü), PC (toplam PL'nin\% 8.0-45.5'i) ve SM'dir (toplam PL'nin \%4.1-\% 29.2'si) ardından PI (toplam PL'nin \%1.4-14.1'i) ve PS (toplam PL'nin \%2.016.1'i) şeklindedir (Lopez ve ark. 2008).

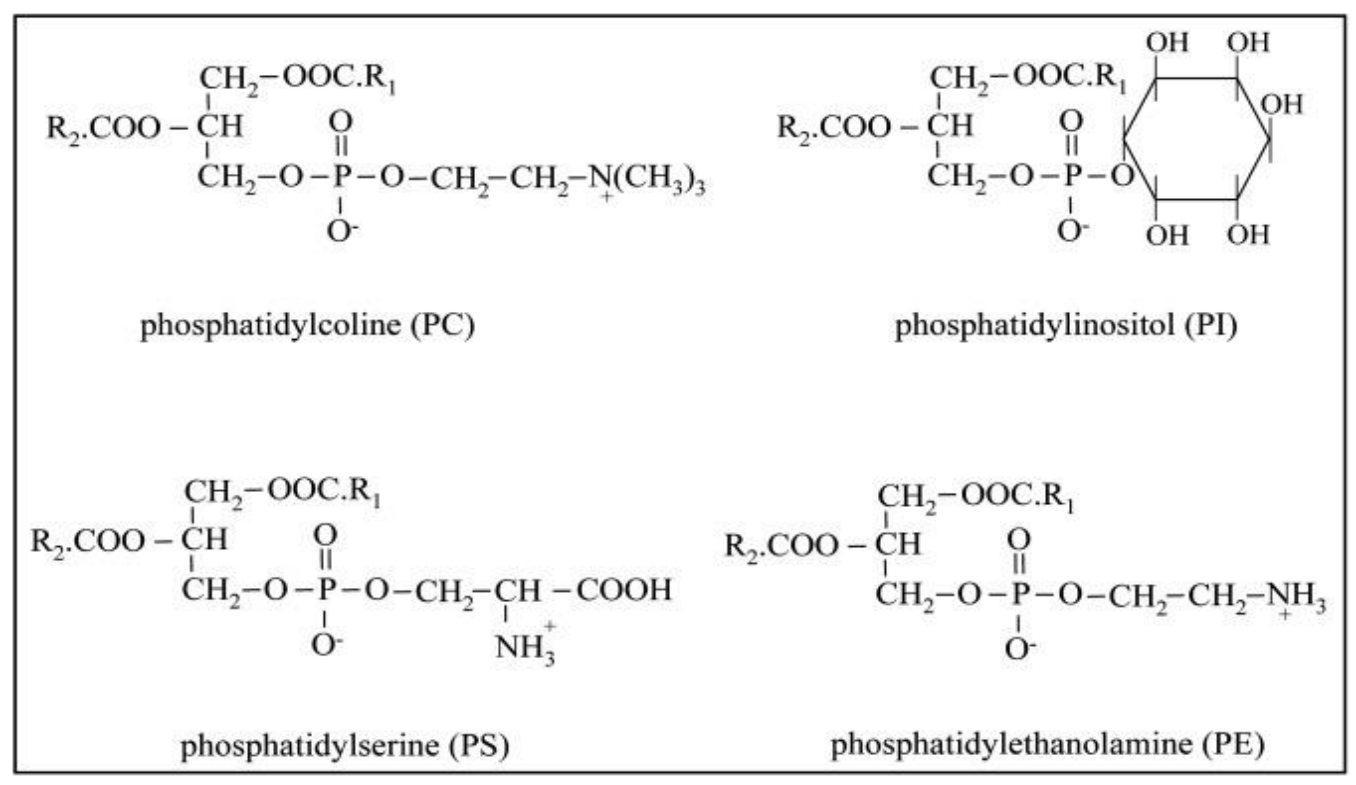

Şekil 2. Süt yağındaki başlıca gliserofosfolipidlerin yapıları (Contarini ve Povolo, 2013)

MFGM yapısında bulunan protein miktarı \%25-60 arasında olup, toplam süt proteinlerinin \%1-4'ünü oluşturmaktadır (Singh, 2006; Cavalettto ve ark. 2008; Vanderghem ve ark. 2010). MFGM'nin ana proteinleri Çizelge 2' de belirtilmiştir.

Keenan ve Mather (2006) tarafindan yapılan bir çalışmada, inek sütünün MFGM preparatlarında başlıcaları ksantin dehidrojenaz/oksidaz, 5'-Nükleotidaz, $\gamma$-glutamil transpeptidaz, katalaz, plazmin, aldolaz olan yaklaşık 28 farklı enzim tespit edilmiştir. Sığı̆ MFGM'sindeki baskın protein ise, toplam MFGM proteini içeriğinin yaklaşık \%40'ını oluşturan bütirofilindir (Abdelmoneim, 2018). Butirofilin, sığır MFGM'sinin önemli bir glikoproteinidir ve Holstein ineklerinden elde edilen sütlerde MFGM ile ilişkili toplam proteinin ağırlıkça \%40'ından fazlasını ve Jersey sütünde yaklaşı \%20'sini içermektedir (Mather ve Jack, 1996). 
Çizelge 1. Toplam fosfolipidlerin yüzdesi olarak verilen fosfolipid bileşenleri (Singh, 2006)

\section{Bileșen}

Trigliserid

Digliseritler

Steroller

Serbest yağ asitleri

Fosfolipidler

Sfingomiyelin

Fosfatidil kolin

Fosfatidil enthanolamin

Fosfatidil inositol

Fosfatidil serin

Lizofosfatidil kolin

\section{Toplam lipitlerin \%'si}

0.6-6.0

26-31

22

36

27

11

4

2

Çizelge 2. MFGM'nin ana proteinleri ve özellikleri (Singh, 2006)

\begin{tabular}{lc} 
Proteinler & Molekül ă̆ırlı̆̆ı (Da) \\
\hline Müsin I (MUC 1) & $160.000-200.000$ \\
Ksantin oksidaz & 150.000 \\
PAS III & $95.000-100.000$ \\
CD36 veya PAS IV & $76.000-78.000$ \\
Butirofilin & 67.000 \\
Adipofilin (ADPH) & 52.000 \\
PAS 6/7 & $48.000-54.000$ \\
Yağ asidi bağlayıcı protein (FABP) & 13.000 \\
BRCA1 & 210.000 \\
\hline
\end{tabular}

\section{Süt Yağı Globül Membranının Sağlık Üzerine Etkileri}

Fonksiyonel içeriği ile dikkat çeken süt yağı globül membranın yapısında bulunduran yayıkaltı suyunun bileşimini Çizelge 3'de verilmiştir. Yayıkaltının en önemli sağlık etkisi yüksek mineral, vitamin, özellikle $\mathrm{B}_{12}$ vitamini, riboflavin ve potasyum içermesinden kaynaklanmaktadır. Ayrıca, yayıkaltı suyu sindirimi kolaylaştırıcı etkiye sahiptir ve laktoz intoleransı olan birçok kişi tarafından kolaylıkla tolere edilebilir. Bununla birlikte, düşük yağ ve kalori içeriği göz önüne alındığında, obezite ile ilişkili hastalıkları olan veya kilo vermeye çalışan insanlar için sağlık riski taşımamaktadır. Yayıkaltı suyu, aminoasit ve yağ asidi sentezinde fonksiyonel bir rol oynayan ve koenzim görevi bulunan $\mathrm{B}_{12}$ vitamini kaynağıdır. $B_{12}$ vitamininin stres ve anemiyi azaltıcı etkisi bulunmaktadır. $B_{12}$ vitamini, ayrıca vücuttaki glikozun enerjiye dönüştürülmesinde yani karbonhidrat metabolizmasında rol oynamaktadır. Yayıkaltı suyu aynı zamanda, kemik sağlığında da önemli bir role sahip olan fosfor ve kalsiyum bakımından zengindir (Abdelmoneim, 2018). 
Son yıllarda, kronik hastalıkların tedavisinde fonksiyonel süt ürünlerinin tüketimi büyük ilgi görmektedir. Süt peptitlerinin, kan basıncının düşürülmesindeki etkisi klinik olarak tanımlanmıştır (Cicero ve ark. 2011). Aromatik amino asit ve hidrofobik kalıntılara sahip küçük süt peptitleri, kan basıncının regülasyonunda yer alan ana enzim olan anjiyotensin dönüştürücü enzim aktivitesini inhibe ederek, fonksiyonel gıdaların geliştirilmesinde temel bileşen olarak ortaya çıkmaktadır. Yayıkaltında büyük miktarlarda bulunan MFGM fraksiyonları, bu özellikleri ile de ilgi çekmektedir (Dewettinck ve ark. 2008).

MFMG'nın ayrıca bağırsak kolesterol alımını da etkilediği belirlenmiştir. Yüksek yağlı bir diyetle beslenen farelerle yapılan bir çalışmada, süt PL'lerinin bağırsak kolesterolünün hepatik birikimini azalttığını ve fekal kolesterol atılımını arttırdığı saptanmıştır (Nilsson ve Duan, 2006; Cohn ve ark. 2010; Kamili ve ark. 2010).

In vitro araştırmalar yayıkaltı suyunda bulunan MFGM'de bulunan PL'lerin kolesterol misel çözünürlüğünü inhibe etme yeteneğine sahip olduğunu ortaya koymuştur (Cohn ve ark. 2010; Conway ve ark. 2010). Süperkritik sıv1 ekstraksiyonu ile izole edilen MFGM'nin rotavirüs enfeksiyonunu önlediği ve bu etkinin kısmen lipit bileşenlerinin yüksek biyoaktif içeriğinden kaynaklanabileceği öne sürülmektedir (Abdelmoneim, 2018).

Yayıkaltı tüketimini takiben toplam kolesterol ve düşük yoğunluklu lipoprotein-kolesterol (LDL) seviyelerindeki azalmanın, esas olarak bağırsak kolesterol alımının inhibisyonundan kaynaklandığı, arteroskleroz için koruyucu etki sağladığı saptanmıştır. Hayvan modeli çalışmalarından elde edilen veriler, yayık altının PL içeriğinin bu etkiden sorumlu olabileceğini düşündürmektedir (Conway ve ark. 2013).

Çizelge 3. Yayıkaltı suyunun bileşimi (Abdelmoneim, 2018)

\begin{tabular}{|c|c|c|c|c|}
\hline & $\begin{array}{c}\text { Düşük yağlı } \\
\text { (low- fat), kültür } \\
\text { ilaveli } \\
\text { yayıkaltı }\end{array}$ & $\begin{array}{c}\text { Yağı azaltılmış } \\
\text { (reduced fat), } \\
\text { külttür ilaveli } \\
\text { yayıkaltı }\end{array}$ & $\begin{array}{c}\text { Reconstitue } \\
\text { yayıkaltı } \\
\text { tozu }\end{array}$ & $\begin{array}{c}\text { Yayıkaltı } \\
\text { tozu } \\
(1 / 4 \text { bardak } \\
=30 \mathrm{~g})\end{array}$ \\
\hline Kalori & 98 & 137 & 93 & 120 \\
\hline Total fat $(\mathrm{g})$ & $1.5(\% 8)$ & $1.5(\% 8)$ & $1.5(\% 8)$ & $1.5(\% 8)$ \\
\hline Önerilen günlük alım (\%) & 5 & 7 & 5 & 6 \\
\hline Doymuş yağ (g) & $1.343(\% 7)$ & $3.043(\% 15)$ & $0.862(\% 4)$ & $1.5(\% 8)$ \\
\hline Tekli doymamış yağ & 0.622 & 1.411 & 0.399 & 0 \\
\hline Çoklu doymamış yağ (g) & 0.081 & 0.174 & 0.051 & 0 \\
\hline Kolesterol (mg) & $10(\% 3)$ & $20(\% 7)$ & $17(\% 6)$ & $20(\% 7)$ \\
\hline Sodyum (mg) & $257(\% 11)$ & $211(\% 9)$ & $127(\% 5)$ & $160(\% 7)$ \\
\hline Potasyum (mg) & 370 & 441 & 382 & 0 \\
\hline Toplam karbonhidrat (g) & $11.74(\% 4)$ & $12.98(\% 4)$ & $11.76(\% 4)$ & $15(\% 5)$ \\
\hline Diyet lifleri $(g)$ & 0 & 0 & 0 & 0 \\
\hline Şekerler $(g)$ & $11.74(\% 4)$ & $12.98(\% 4)$ & $11.76(\% 4)$ & $15(\% 5)$ \\
\hline Protein $(\mathrm{g})$ & 8.11 & 10,04 & 8.23 & 10 \\
\hline A vitamini (\%) & 1 & 3 & 1 & 0 \\
\hline $\mathrm{C}$ vitamini (\%) & 4 & 6 & 2 & 0 \\
\hline Kalsiyum (\%) & 28 & 35 & 29 & 35 \\
\hline $\operatorname{Demir}(\%)$ & 1 & 1 & 0 & 0 \\
\hline
\end{tabular}

Farklı bir çalışmada PL ve sfingolipid bileşimlerine sahip yayıkaltı sularının insan kaynaklı bir kolon kanseri hücresinde büyüme modülatör etkileri incelenmiştir. Yayıkaltı, yıkanmış ve yıkanmamış kremadan santrifüj etkisi ile elde edilmiştir. Tespit edilen majör sfingolipidler sfingomiyelin (\%10.429.5) ve laktosilseramid (\%1.2-44.3) olarak saptanmıştır. Yayıkaltı örneklerinin in vitro incelenmesinde, doza bağlı olarak, SW480 antiproliferatif aktivite tümör kanseri hücrelerine karşı seçici olarak kolon kanseri hücrelerinin büyümesinde inhibisyon etkisi tespit edilmiştir (Kuchta-Noctor ve ark. 2016).

Liutkevičius ve ark. (2016) tarafından, fonksiyonel fermente yayıkaltı bazlı içecek üretim yöntemi geliştirilmiş ve içecek alımının insan sağlı̆̆ parametreleri üzerindeki etkisi araştırılmıştır. Kalite özellikleri (viskozite, serum ayrılması, duyusal özellikler ve toplam kabul edilebilirlik) değerlendirilmiştir. İçecekte, \%0.3 süt proteini konsantresi kullanılmıştır. Tıbbi beslenme deneylerine dayanarak, süt proteini konsantresi ile takviye edilmiş fermente yayıkaltı içeceğinin 3 . haftadan sonra 25

16 | P a g e 
genç gönüllünün biyokimyasal kan parametreleri üzerinde önemli bir etkisi gözlenmemiştir. Ayrıca, hastalarda, kolesterol, yüksek yoğunluklu kolesterol (LDL) ve triaçilgliserol seviyeleri azalmıştır. Ancak antropometrik vücut ölçüsü, vücut kompozisyonu, nabız değerlendirme indeksi ve arteriyel kan basıncında önemli bir değişiklik olmamıştır (Abdelmoneim, 2018).

Süt sfingolipidleri ve PL'lerin kolon kanserine ek olarak, özellikle insan yumurtalık kanseri hücre hatlarına karşı antiproliferatif aktivite gösterdiği saptanmıştır. Bununla birlikte, yayıkaltından izole edilmiş lipit fraksiyonlarının antiproliferatif etkisinin doğru mekanizmalarının netleştirilmesi ve sfingolipidlerin ve PL'lerin hayvan modellerinde olası antikanser özelliklerinin in vitro ve in vivo araştırılması gerektiği belirlenmiştir (Castro-Gómez ve ark. 2016).

İmmün sistem düzenleme ve MFGM izolatlarının antikanserojen potansiyellerine ait araştırma pek çok çalışmanın odak noktasını oluşturmuştur. İnek sütünden elde edilen MFGM izolatı HT-29 hücreleri (bir kolon kanseri hücre çizgisi) üzerinde antiproliferatif etki göstermiştir. Programlanmış bir marker olan kaspaz-3'ün aktivasyonu ile hücre ölümünü gerçekleştirmiştir (Zanabria ve ark. 2013). Benzer sonuçlar, epitel kolorektal adenokarsinom hücresi için de bulunmuştur. MFGM fraksiyonlarının ekstraksiyoundan önce sütün $80^{\circ} \mathrm{C}$ 'de 10 dakika boyunca 1 sıl işlem görmesi ile önemli ölçüde biyoaktivite değerinin azaldığı saptanmıştır (Zanabria ve ark. 2014b).

Son yıllarda MFGM fraksiyonlarının antimikrobiyel özellikleri tanımlanmıştır. Tüm membran fraksiyonlarının Escherichia coli O157: H7 veya Listeria monocytogenes' in daha az duyarlılıkla ise Salmonella typhimurium ve Pseudomonas fluorescens' in çoğalmalarını önlediği saptanmıştır (Clare ve ark. 2008). MFGM fraksiyonlarının antimikrobiyel aktivitesi, sadece in vitro olarak değerlendirilmemektedir. Yapılan bir çalışmada, bebeklerde ortaya çıkan akut otitis riskinin, sığır MFGM fraksiyonları (proteine bağlı olarak ağırlıkça \%4 içeriğe sahip) içeren bir diyet ile takviye yapılarak azaldığ 1 belirlenmiştir (Timby ve ark. 2015). Farelerde Helicobacter pylori enfeksiyonunun inhibisyonu 400 mg/kg MFGM izolatı kullanılarak inhibe edilmiştir (Wang ve ark. 2001).

Yayıkaltı suyuveya peynir altı suyundan izole edilen bütün ekstraktların rotavirüse karşı anti-enfektif aktivite gösterdiği ve bunun lipit bileşenlerinden kaynaklandığı ifade edilmiştir (Fuller ve ark. 2013). MFGM'nin polar lipidleri (fosfolipidler ve sfingolipidler) kolesterolü düşürücü ve antienflamatuar etkilere sahiptirler ve ayrıca sinir sisteminin fonksiyonlarını olumlu yönde etkilemektedirler (Jiménez Flores ve Brisson, 2008; El- Loly, 2011; Liutkevičius ve ark. 2016; Skryplonek ve ark. 2019). Sfingolipidler bağırsaktaki emici epitelyumdaki apikal membranda bol miktarda bulunmaktadır (Danielsen ve Hansen, 2006).Sindirim metabolitleri (seramidler ve sfingozin) hücre fonksiyonları üzerinde önemli etkileri olan en biyoaktif bileşikler olarak kabul edilmektedir. Bu bileşikler, membran yapısının korunması, büyüme faktörü reseptörlerinin davranışının modülasyonu ve bazı mikroorganizmalar, mikrobiyel toksinler ve virüsler için bağlanma yerleri olarak etki etmektedir (Vesper ve ark. 1999). Seramidler, hücre proliferasyonunu inhibe eden ve apoptosisi indükleyen bir lipid habercisidir. Oysa sfingosin-1-fosfat hücre içinde ikinci bir habercidir ve ikinci molekülün hücre büyümesinin, anjiyogenezin, bağışıklık fonksiyonunun düzenlenmesinde önemli rolünü gösteren kanıtlar bulunmaktadır (Duan ve Nilsson, 2009; Contarini ve Povolo, 2013).

Yağ içeren süt ürünleri önemli bir sfingolipid kaynağıdır. Ortalama insan diyet PL alımının yumurta, tahıl taneleri, yağlı tohumlar, balık, sığır eti ve inek sütü gibi farklı gıda türleri ile birlikte 2-8 g/gün olduğu tahmin edilmektedir (Contarini ve Povolo, 2013). MFGM'nin yapısında bulunan sfingolipidler ve metabolitleri, kanser hücreleri üzerinde çoğalmaya karşı aktivite göstermektedir. Polar lipid tabakaları arasında bulunan bir protein olan ksantin dehidrojenaz ve oksidaz (XDH / XO), antibakteriyel etkiye sahiptir ve dış çift tabakada bulunan büyük bir glikosile protein olan MUC1, enterik bakterilerin gastrointestinal epitelyuma bağlanmasını engellemektedir (Martin ve ark. 2004; Parker ve ark. 2010; Arranz ve Corredig, 2017).

MFGM fraksiyonlarının antienflamatuar etkisinin olduğu da yapılan çalışmalarla kanıtlanmıştır (Demmer ve ark. 2016). MFGM izolatlarının (10 mg/kg LPS ve \%12.5 MFGM diyet takviyesi) farelerde lipaz- lysophosphatidylserine tarafından indüklenen sistemik enflamatuar yanıtı azalttığı belirlenmiştir. İzolatlarla beslenen hayvanların kontrol hayvanlarına göre daha düşük serum proinflamatuar sitokin seviyeleri saptanmıştır (Snow ve ark. 2011).

Son çalışmalar, artan süt ve süt ürünleri tüketiminin, kalp-damar hastalıkları için risk faktörleri olan obezite, insülin direnci, dislipidemi ve tip 2 diyabet insidansında azalma ile ilişkili olduğunu göstermiştir (Pereira ve ark. 2002; Choi ve ark. 2005). Wat ve ark. (2009) sütten türetilen PL'lerin farelerde plazma ve karaciğerin lipit metabolizması üzerindeki etkisini araştırmış ve yüksek yağlı diyet ve fosfolipid açısından zengin bir süt fraksiyonu ile takviyesinin toplam karaciğer lipit, trigliserit, toplam kolesterol

17 I P a g e

www.iiste.org 
ve serum lipitlerinde önemli bir azalmaya neden olduğunu gözlemlemişlerdir. Sindirim sisteminin mukozal yüzeyi, potansiyel olarak zararlı faktörlerin geniş bir yelpazesi arasındaki bir engeli temsil etmektedir ve polar lipidler, hücre zarlarının korunmasında etkilidirler (Kuchta ve ark. 2012). VeeremanWauters ve ark. (2012) küçük çocuklar tarafindan MFGM ile zenginleştirilmiş bir süt tüketiminin gastrointestinal enfeksiyonlara karşı koruyucu bir etkiye sahip olduğu ve ateş nöbeti dönemlerin sayısında önemli bir azalmaya yol açtığını belirlemişlerdir. Süt bazlı fosfalipidler (PL), kronik stres altındaki bireyler üzerinde olumlu etkiler göstererek, organizmanın duruma uyum sağlama yeteneğini geliştirmekte, kortizol kullanılabilirliğini arttırmakta ve stres kaynaklı hafıza bozukluklarını azaltmaktadır (Schubert ve ark. 2011). Hellhammer ve ark. (2010) fosfatidilserin ve sfingomiyelin açısından zengin PL konsantrasyonunun günlük alımda hafiza ve akut stres yanıtı üzerinde benzer yararlı etkilere sahip olup olmadığını araştırmışlardır. PL ile tedavi edilen deneklerde, plaseboya maruz bırakılan kişilere kıyasla, çalışma hafızasında daha kısa reaksiyon süreleri eğilimi ile daha iyi bir tepki gözlenmiştir. İki tedavi grubu, endokrin stres yanıtlarında önemli bir farklılık göstermemiştir. Bununla birlikte, daha yüksek stres yüküne sahip PL ile tedavi edilen denekler, daha fazla bir psikolojik stres yanıtı göstermiştir.

Diyetteki farmakolojik olmayan sfingomiyelin miktarları, farelerde kimyasal olarak indüklenen kolon kanseri üzerinde kemopreventif ve kemoterapötik etkiler göstermiştir (Lemonnier ve ark. 2003). Diğer hücre tipleri üzerinde yapılan çalışmalar, sfingolipidlerin $\gamma$-ışınlaması ve kimyasal ajanlardan kaynaklanan hasarlara karşı bile koruyucu bir aktiviteye sahip olabileceğini göstermektedir (Vesper ve ark. 1999). Russell ve ark. (2010) süt PL'lerinin ve özellikle SM'nin cilt hücrelerine etki ederek onları ultraviyole radyasyonun etkisine karşı koruduğunu ileri sürmektedir.

Oshida ve ark. (2003) gelişmekte olan sıçanlarda, diyetsel SM'nin merkezi sinir sisteminin miyelinasyonuna katkıda bulunabileceğini göstermiştir; ayrıca Tanaka ve ark. (2012) prematüre bebeklerde sfingomiyelin ile kuvvetlendirilmiş sütün uygulanmasının nörodavranışsal gelişim ile pozitif bir ilişkisi olduğunu göstermiştir.

PL'ler, zarın akışkanlığı için çok önemli moleküller olan esansiyel çoklu doymamış FA'ların taşıyıcılarıdır. Bu fonksiyon yaşlanma sırasında oldukça önemlidir, çünkü bu dönemde beyin hücrelerinin lipit bileşimi değişmekte ve çoklu doymamış n3-FA içeriği azalmaktadır. PC ayrıca alkole bağlı beyin hücresi değişikliklerinin de tedavisinde antioksidatif ajan olarak rol oynamakta ve kolin beyin gelişimini ve yaşam boyu hafıza özelliklerini etkilemektedir (Küllenberg ve ark. 2012).

Son olarak, diyet PL'lerinin Alzheimer hastalı̆̆ına terapötik yaklaşımda katkıda bulunabileceği hipotezini destekleyen çalışmalarda bulunmaktadır. Alzheimer ve Parkinson gibi nörodejeneratif hastalıklara endoplazmik retikulum stresi neden olmaktadır (Lindholm ve ark. 2006). Nagai (2012) süt PL'lerinin endoplazmik retikulum stresine bağlı nöronal hücre ölümü üzerindeki koruyucu fonksiyonunu belirlemiş, süt PL'lerinin veya süt ürünlerinin tüketiminin bazı nörodejeneratif hastalık riskini azaltabileceği sonucuna varmıştır.

Bezelgues ve ark. (2009) tokoferol ve likopen ile yapılan bir in vitro sindirim çalışması ile, MFGM ile saflaştırılmış fraksiyonun, lipo-çözünür moleküllerin safra tuzları misellerine aktarılmasında diğer geleneksel emülsifiye edici süt proteinlerinden daha yüksek bir yeteneğe sahip olduğunu belirlemişlerdir.

\section{Süt Yağı Globül Membranının Teknolojik Özellikleri}

Yayıkaltı suyu, tereyağı üretiminde kremanın yayıklanması sırasında ortaya çıkan sulu fazdır ve hammaddeye, ön işlem koşullarına ve tereyağı üretim sürecine göre çeşitli süt yağı bileşenlerini içermektedir. En yaygın kullanılan yayıkaltı suyu, tatlı kremanın tereyağı üretiminde kullanılması ile elde edilen tatlı yayıkaltı suyudur. Bununla birlikte, kültürlü kremanın yayıklanması ile de üretilen üretilen ekşi yayıkaltı suyu ile de birlikte, tüm bu yayık altı suları zengin MFGM içerikleri ile, konsantre, UF ya da toz formda çeşitli gıdaların teknolojik özelliklerini geliştirmek için kullanılmaktadır (Avci and Ozcan, 2020).

Yağsız süt tozu ile üretilen peynirle karşılaştırıldığında, MFGM bileşenleri (süte eklenen yayıkaltı tozu formunda), peynir olgunlaşması sırasında laktik asit bakterinin gelişimi üzerinde düşük bir etkiye sahip olurken, yayıkaltı tozu ilavesiyle üretilen peynirde peynir matriksinde daha pürüzsüz, daha homojen bir protein ağ 1 ve peynir matriksi içinde daha üniform bir dağılımı tespit edilmektedir (Vanderghem ve ark. 2010; Abdelmoneim, 2018).

Farklı bileşime sahip yayıkaltı suları emülsifiye edici bileşenler açısından oldukça zengindirler. Burada, kazein, peynir altı suyu proteinleri ve MFGM proteinleri doğal emülsifiye edici bileşenler olarak görev yapmaktadırlar. Kazeinler, sığır sütünün ana proteinleridir ve yüksek prolin içerikleri nedeniyle düzensiz

18 | P a g e

www.iiste.org 
bir yapıya sahiptirler. Ayrıca, kazein esnek, değişime yatkın bir özellik gösterir ve birincil yapılarında ara birimlerde adsorpsiyona izin veren amfifilik niteliklere sahiptir. Özellikle, ß-kazein, köpürme veya emülsifikasyon sırasında, yeni oluşan arayüzde gerilimi hızla azaltabilmektedir. Peynir altı suyu proteinleri ise küresel yapılı proteinlerdir. Yüzey gerilimini kazeinler kadar hızlı düşürmezler, ancak arayüzlerde sıkıca kümeleşmiş bir viskoelastik yapı oluşturabilirler ve uzun süreli stabiliteyi de desteklemektedirler. MFGM'nin emülsifiye edici bileşenleri ise, membran proteinleri ile fosfolipidlerdir ve amfifilik doğaları nedeniyle doğal emülsifiye edici maddeler olarak düşünülebilmektedirler (Vanderghem ve ark. 2010).

Yağ globül zarının önemli etkisi sütteki yağı stabilize etmektir. Phipps ve Temple (1982), yağ globüllerinin arayüzey geriliminin $2 \mathrm{mN} \cdot \mathrm{m}^{-1}$ den daha düşük olduğunu ve bunun emülsifiye edici özelliklerini açıklayabileceğini belirtmişlerdir. MFGM proteinlerinin ve fosfolipidlerinin sütteki yă̆ globüllerinin stabilizasyonundaki rolü yapılan çalışmalarla araştırılmıştır. Shimizu ve ark. (1980), yağ globüllerinin birleşmesini, fosfolipidlerin iyonojenik gruplarından türetilen itici kuvvetlerle engellendiği sonucuna varmışlardır. Buna karşılık Scott ve ark. (2003a) yayıkaltı suyu emülsiyonlarının saklama sırasında yağsız sütle formüle edilmiş kremaya kıyasla daha uzun süre stabil kaldığını belirtmişlerdir. Bu sonuçlar, farklı yayıkaltı türlerinin (ticari tatlı yayıkaltı ve ekşi yayıkaltı) yağsız süt ve peynir altı suyuna kıyasla daha yüksek emülsifikasyon özellikleri gösterdiğini tespit eden diğer araştırmacılar (Sodini ve ark. 2006) tarafindan da desteklenmektedir.

Birçok çalışma, endüstriyel bir yayıkaltından konsantre MFGM izolatları elde etmeye odaklanmıştır. MFGM izolatları, kazein misellerini ayırmak için sodyum sitrat ilave edildikten sonra ultrasantrifüj yoluyla ticari yayıkaltından elde edilebilmektedir. Bu MFGM izolatının, tüm yayıkaltı izolatına kıyasla çok zayıf emülsifiye edici özelliklere sahip olduğu kanıtlanmıştır. Yapılan araştırmalarda, kremada ve yayıklamada uygulanan ısıl işlemin, yüksek derecede agregasyona ve membran proteinlerinin ve fosfolipidlerin fonksiyonel özelliklerinde değişikliklere neden olduğu sonucuna varılmıştır. Benzer bir çalışmada Roesch ve ark. (2004), MFGM izolatları ve bir yayıkaltı konsantresi arasındaki fonksiyonel farklılıklarını test etmişledir. Çalışmaları, yüksek ısıl işleme tabi tutulmuş yayıkaltından elde edilen MFGM izolatlarının, tüm yayıkaltı konsantre örneklerinden daha iyi kıvamlandırma stabilitesi ve daha küçük yağ damlacık boyutu dağılımı olduğunu göstermektedir. Kremanın değişkenliği ve kalitesi ile birlikte, tereyağı işlenirken ön işlemlerin ve konsantre MFGM izolatları elde etme yönteminin de son ürünün tekno-fonksiyonel özellikleri etkileyebileceği vurgulanmıştır (Vanderghem ve ark. 2010).

Krema tereyağı üretiminden önce ısıtıldığında MFGM'de meydana gelen değişiklikler araştırmacılarca dikkat çekmiştir. Kremaya uygulanam 1 sıl işlemin, peynir altı suyu proteinlerinin MFGM ile birleşmesine neden olarak çözünürlüğü etkilediği ve MFGM izolatlarının emülsifiye edici özelliklerini azalttığı tespit edilmiştir. $65^{\circ} \mathrm{C}$ kadar düşük sıcaklıklar bile bu membran fraksiyonunun fonksiyonel özelliklerini güçlü bir şekilde etkilenmektedir. Gassi ve ark. (2008) kremanın 1sıl işleminin tatlı yayıkaltı suyunun fizikokimyasal özelliklerini etkilediğini belirtmişlerdir. Isıl işlem, yayıkaltı suyu çözünür protein içeriğinde önemli bir azalmaya ve ayrıca yayıkaltı fosfolipid/yağ oranında da bir artışa neden olmaktadır (Corredig ve ark. 1998b).

Gıda endüstrisinde yayıkaltı suyu, hacminin azaltılması amacıyla, buharlaşma ve spreyle kurutma işlemleriyle yayıkaltı tozu şeklinde üretilmektedir. Konsantre ya da kurutulmuş yayıkaltı katkıları, MFGM fraksiyonlarının varlığı nedeniyle gıda matriksinin su bağlama yeteneğini geliştirmek için yoğurt üretimi gibi çeşitli alanlarda kullanılmaktadır (Le ve ark. 2011; Saffon ve ark. 2013; Romeih ve ark. 2014). Unlu ürünlerde, hamur oluşumu sırasında yayıkaltı tozunun eklenmesi, tekstürel yapıyı iyileştirmiştir (Madenci ve Bilgiçli, 2014). Fosfo- ve glikolipid içeriği ile, yayıkaltından ekstrakte edilen MFGM bileşenlerinin, farmasötik ve bebek maması endüstrilerinde fonksiyonel katkı olabileceği de belirtilmiştir (Spitsberg, 2005).

Ayrıca yayıkaltı, çikolata, salata sosları ve peynir gibi çok sayıda gıda ürününde tekstürel özelliklerin geliştirilmesi, sürülebilirliğin ve randımanın arttırılması amacıyla teknolojik bir bileşen olarak da kullanılmaktadır (Govindasamy-Lucey ve ark. 2006; Morin ve ark. 2008).

Çalışmalarda, peynir üretiminde konsantre veya UF uygulanmış yayıkaltı suyunun kullanıldığı belirtilmektedir. Ticari yayıkaltı üretiminde, kremanın pastörizasyon sicaklıkları, fermantasyon, buharlaşma sırasında bekletme süresi gibi yayıkaltının tekno-fonksiyonel özellikleri üzerinde önemli etkileri olan sprey kurutma işleminin değişken işleme koşullarına maruz kalmaktadır (Morin ve ark. 2008). Bu nedenle, peynir sütüne yayıkaltı ilavesi ile fiziksel ve tekstürel özellikler üzerindeki etkiler bu bileşim farklılıklarından dolayı tam olarak açıklanamamaktadır. Peynir üretiminde yayıkaltı ilavesi, peynir sütünün çok sayıda kaynaktan (tatlı, ekşi ve peynir altı suyu) ve yoğunlaştırılmış, UF, toz veya

19 | P a g e

www.iiste.org 
geleneksel yayıkaltı ilavesi şeklinde ve farklı peynirlerde uygulaması olarak araştırılmıştır (Morin ve ark. 2008, Kifah ve ark. 2014). Yayıkaltı ilavesi denatüre peynir altı suyu proteinleri ve amfipolar PL'lerin varlığı nedeniyle peynir pıhtısındaki nem içeriğini artırmaktadır. Peynir altı suyu proteinleri, kkazein ile etkileşime girerek kazein-peyniraltı suyu proteini komplekslerini oluşturmaktadır. Pıhtılaştırıcının k - kazeine etkisinin azalması ile peynir mayası ile pıhtılaşma süresi artmakta, peynir tekstürü yumuşamaktadır (Abdelmoneim, 2018).

Hamed (2010), eritme peyniri üretiminde konsantre tatlı yayıkaltı suyu kullanımının duyusal özellikleri geliştirdiği ve depolama süresindeki artışla erime kabiliyetini azalttığı sonucuna varmıştır. Bir çalışmada, konsantre yayıkaltı suyu, az yağlı peynir sütünü PL'lerle desteklemek için kullanılmıştır. Peynirdeki PL'lerin artışı ile, artan nem içeriği, daha yüksek primer proteoliz ve ac1/kokuşmuş bir aroma oluşturmuştur. Daha yüksek PL içeriğine sahip az yağlı peynir ise daha yumuşak bir tekstüre ve parçalı bir mikro yapıya sahip olarak tespit edilmiştir (Turcot ve ark. 2002). Romeih ve ark. (2012) ve Martinovic ve ark. (2013) peynir sütünün yayıkaltı suyu tozu ile takviye edilmesinin ve MFGM fraksiyonlarının mikroyapı üzerindeki etkisini düşük yağlı Cheddar peynirinde araştırmışlardır. Süte ilave edilen yayıkaltı tozundaki MFGM bileşenlerinin, peynir olgunlaşması sırasında yağsız süt tozu ile üretilen peynirle karşılaştırıldığında starter olmayan laktik asit bakterinin gelişimi üzerinde düşük bir etkiye sahip olduğunu ve yayıkaltı tozu ilavesiyle üretilen peynirde peynir matriksinde daha pürüzsüz, daha homojen bir protein ağ 1 ve üniform bir dağılım şekillendiğini tespit etmişlerdir.

Tereyağ üretiminde kremann $85-95^{\circ} \mathrm{C}$ 'de en az 15 saniye veya daha fazla pastörizasyonu önerildiği için yayıkaltı suyunun yoğun bir isıl işleme tabi tutulması beklenmektedir. Tereyağı işleme sırasında kremanın 1sıl işlemi, kremadaki peynir altı suyu proteinlerinin MFGM ile bağlanabilen belirli bir derecedeki denatürasyonunu içermektedir. Bu etkide peynir üretimi için kullanılan yayıkaltı suyunun özelliklerini de etkileyecektir; örneğin, sonuçta elde edilen peynirlerin su bağlama kapasitesinin artması gibi (Abdelmoneim, 2018). Romeih ve ark. (2012) yayıkaltı sütünün peynirin yağ kürecikleri üzerinde emülsifiye edici bir etkiye sahip olduğunu ve peynirin mikroyapısı incelendiğinde de, peynirin daha yumuşak bir yapı gösterdiğini saptamışlardır.

Morin ve ark. (2008), peynir sütüne ilave edilen yayıkaltı suyunun; pıhtı kesim süresini arttırdığını ve jel sıkılığını azalttığını gözlemlemişlerdir. Yayıkaltı suyu içeren peynir sütünün pıhtılaşma davranışı, yayıklamadan önce kremanın 1 sıl işlem etkinliğine ve yayıkaltı suyunda bulunan MFGM fraksiyonlarına bağlanmıştır. Skeie ve ark. (2013) peynir sütüne \%15 yayıkaltı suyu ve $\% 3$ mikro parçacıklı peynir altı suyu proteinlerinin eklenmesinin düşük yağlı Norvegia peyniri tekstürünü geliştirdiğini, peynirin sertliğini ve lastiğimsi dokusunu azalttı̆̆ını bildirmişlerdir.

Tatlı kremadan elde edilen yayıkaltı suyununn bileşimi, yüksek PL'ler ve MFGM protein içeriği dışında yağsız sütün bileşimine benzemektedir. Yapılan bir çalışmada, tam yağlı süt yerine farklı miktarlarda tatlı krema yayıkaltı suyu $(5,10,16,20,26,30,36,40,45$ ve \%50) kullanılarak krem peynir üretilmiştir. Tatlı krema yayıkaltı suyu içeriği matrikste artırılarak, toplam kuru madde, protein, yağ, kuru maddede yağ ve peynir sütünün kül içeriği önemli ölçüde azalmış, daha yumuşak ve nemli bir pıhtı ortaya çıkmıştır. \%25'ten fazla yayıkaltı suyu içeren peynir örneklerinin tadı duyusal olarak beğenilmezken, $\% 25$ ve \%30 tatlı kremalı yayık altı suyu kullanılarak üretilen krem peynir, en yüksek randımana sahip olmuştur (Bahramini ve ark. 2015).

Üretim sürecinin kolaylığı ve yüksek besin değeri nedeniyle, yayık altı suyu dünya çapında günlük bir diyet içeceği olma potansiyeline sahip bulunmaktadır. Aloe vera suyu içeren yeni bir yayıklaltı suyu içeceği lif takviyesi ile birlikte hazırlanmış, fizikokimyasal ve duyusal özellikler araştırılmıştır. Lif ilavesi (\%1-5), yayıklatı suyu içeceğinin asitliği ve pH'ında önemli bir değişikliğe neden olmamıştır. Bununla birlikte, \%5 lifli yayıkaltı suyu içecekleri daha yüksek viskozite ve daha düşük serum ayrılması göstermiştir. \%4 lif içeren içecekler ise duyusal değerlendirmede en yüksek puanları almıştır. Yayıkaltı suyu örneklerinin viskozitesi, lif ilavesi konsantrasyonu ile ilişkili olarak eşit olarak artmıştır. Yayıkaltı suyunda, \%4 çözünür diyet lifi ile yapılan zenginleştirme, besin değeri ile birlikte, fizikokimyasal ve duyusal özellikleri geliştirmiştir (Mudgil ve Barak, 2016).

Ön filtrasyon ve UF gibi çeşitli filtrasyon yöntemleri uygulanmış ve ananas, mango ve portakal suları daha besleyici ve duyusal olarak kabul edilebilir yayıkaltı suyu içeceği üretilmiş ve $\% 12$ şeker ve \%24 ananas suyu ile ve UF üretilen içecek daha çok beğenilmiştir (Shaikh ve Rathi 2009). Başka bir çalışmada, peynir altı suyu protein konsantresi tozu ve yayıkaltı suyu tozu, mayalanmış ve mayasız yassı ekmek hamurunda farklı konsantrasyonlarda (\%0, 4 ve 8) kullanılmıştır. Peynir altı suyu proteini konsantresi tozu ve yayıkaltı suyu tozunun hamurun reolojik özellikleri üzerindeki etkileri ekstensogram ve farinogram parametreleri kullanılarak değerlendirilmiştir. Genel olarak, peynir altı suyu proteini

20 | P a g e

www.iiste.org 
konsantresi tozu ve yayıkaltı suyu tozu ilavesi, hamur stabilitesi, maksimum direnç değerleri ve uzama direnci açısından hamur özelliklerini geliştirmiş ve protein içeriğini yükseltmiştir (Madenci ve Bilgicli, 2014).

Nişasta-yayıkaltı suyu karışımı filmlerinin mikro yapısal olarak incelendiği bir çalışmada, filmlerin daha uzayabilir fakat çok yumuşak hale geldiği, film gerilme kabiliyetinde dikkate değer değişiklikler olmaksızın film sertliğinde ve kırılma direncinde önemli bir azalma sağlanmıştır. Yayıkaltı suyu, nişasta filmlerinin su buharı geçirgenliğini de güçlendirmiştir (Moreno ve ark. 2014). Partikül boyutu dağılımı ve viskozite ölçümleri, MFGM ve dolayısıyla PL tarafından zenginleştirilmişs süt ürünlerinin, örneğin tatlı yayıkaltı tozu ve krema kalıntı tozu gibi, esasen rekombinasyona tabi tutulan buharlaştırılmış sütün 1S1 stabilitesini arttırdığını göstermiştir. $121^{\circ} \mathrm{C}$ 'de sterilizasyon koşullarındaki isıl işlemde, PL içermeyen örneklerde peynir altı suyu proteininin denatürasyonu ve peynir altı suyu proteini-kazein etkileşiminden kaynaklandığı düşünülen katı jel yapı oluşumuna yol açmıştır. MFGM kaynakı1 PL'lerin ise, 1sı stabilize edici özelliklerinin pozitif etkisinin olduğu saptanmıştır. Yayıkaltı suyu ve \% 10 ayçiçek yağı kullanılarak protein denatürasyonunun manipüle edildiği stabil bir model emülsiyonun da oluşturulabileceği Guggisberg ve ark. (2012) tarafından belirtilmiştir.

Lipozomlar ilaç ve kozmetik endüstrisinde, ilaçların veya nutrasötiklerin, model membranlar veya hücreler olarak tuzaklanması ve kontrollü salımı için kullanılmaktadır. Gıda endüstrisinde ise lipozomlar, bazı hassas biyoaktif bileşenlerin korunmasından, gıda katkı maddelerinin etkinliğinin artırılmasına ve istenmeyen lezzetlerin sınırlandırılmasına kadar birçok potansiyel uygulama bulunmaktadır (New, 1990). Biyoaktif bileşiklerin kapsüllenmesi ve kontrollü salınımı, stabilitenin ve biyoyararlılığın arttırılması için kullanılan lipozomlar, süt PL'leri ile iki tabakalı veziküllerin hazırlanması için başarıyla test edilmiştir. Gulseren ve ark. (2012) potansiyel biyoaktif moleküllerin iletimini optimize etmek amacıyla polifenollerin kapsüllenmesi için süt PL'lerini uygulamışlardır. Farhang ve ark. (2012) PL'leri, hem vitamin takviyesi hem de antioksidan olarak kullanılabilen çok kararsız bir bileşik olan askorbik asidin kapsüllenmesi için kullanmışlardır.

\section{Sonuç}

Yayıklaltı suyu, MFGM fraksiyonları ile birlikte yağsız süt türevleri olan proteinler (kazein ve peynir altı suyu proteinleri), laktoz ve mineralleri yüksek oranda içermektedir. Bu nedenle, biyoaktif içeriği yüksek ve sağlık üzerine etkileri tanımlanmış MFGM fraksiyonlarını ayırmak için esas olarak membran filtrasyonuna dayanan saflaştırma işlemlerine ihtiyaç duyulmaktadır. MFGM hakkında son yıllarda çok miktarda bilimsel çalışma yapılmıştır. Modern proteomik tekniklerin uygulanması da ayrıca MFGM'nin küçük protein bileşenlerinin saptanmasına ve tanımlanmasına izin verecektir. Bu tür teknikler sonunda MFGM proteinleri ve yağsız süt proteinleri arasındaki karmaşık etkileşimlerin karakterizasyonu ve teknolojik etkileri değerlendirilebilecektir. Protein ve fosfolipid bileşenlerinin ayrılması, mevcut tekniklerin MFGM proteinlerinin denatürasyonuna ve agregasyonuna neden olma eğilimi nedeniyle karmaşıktır. MFGM' nin süt kaynaklarından saflaştırılması ve potansiyel uygulamalarının geliştirilmesi için daha fazla araştırmaya ihtiyaç bulunmaktadır. Nispeten büyük miktarlarda ve yüksek kaliteli MFGM biyoaktif bileşenlerinin saflaştırılması, MFGM'nin insan sağlığındaki rolü üzerine daha fazla çalışmayı kolaylaştıracak ve bu nutrasötik bileşenin insanlarda kontrollü klinik koşullar altında test edilmesine izin verebilecektir.

\section{Kaynaklar}

Abdelmoneim, H.A. (2018). Current knowledge of buttermilk: Composition, applications in the food industry, nutritional and beneficial health characteristics. International Journal of Dairy Technology, 72, 169-182.

Argov, N., Wachsmann- Hogiu, S., Freeman, S.L., Huser, T., Lebrilla, C.B., \& German, J.B. (2008). Size dependent lipid content in human milk fat globules. Journal of Agricultural and Food Chemistry, 56, 7446-7450.

Argov-Argaman, N., Smilowitz, J.T., Bricarello, D.A., Barboza, M., Freeman, S., Lebrilla, C.B., Parikh, A.N., \& German, J.B. (2010). Lactosomes: structural and compositional classification of unique nanometer- sized protein lipid particles of human milk. Journal of Agricultural and Food Chemistry, 58, 11234-11242. 
Arranz, E., \& Correding, M. (2017). Milk phospholipid vesicles, their colloidal properties and potential as delivery vehicles for bioactive molecules. Journal of Dairy Science, 100, 4213-4222.

Avci, H.R., \& Ozcan, T. (2020). The characterisation of dairy industry waste buttermilk from different butter processing procedures. Fresenius Environmental Bulletin, 29, 5472-5478.

Bahrami, M., Ahmadi, D., Beigmohammadi, F., \& Hosseini, F. (2015). Mixing sweet cream buttermilk with whole milk to produce cream cheese. Irish Journal of Agricultural and Food Research, 54, 73-78.

Bezelgues, J.B., Morgan, F., Palomo, G., Crosset-Perrotin, L., \& Ducret, P. (2009). Milk fat globule membrane as a potential delivery system for liposoluble nutrients. Journal of Dairy Science, 92, 2524-2528.

Birch, C., \& Bonwick, G. (2019). Functional foods processing: Maximising consumer benefit and producer confidence. Institute of Food Science Techology, 54(5), 1433-1437.

Castro- Gomez, P., Rodriguez-Alcala, M., Monteiro, K. M., Ruiz, A.L., Carvalho, J. E., \& Fontecha, J. (2016). Antiproliferative activity of buttermilk lipid fractions isolated using food grade and non-food grade solvents on human cancer cell lines. Food Chemistry, 212, 695-702.

Cavaletto, M., Giuffrida, M.G., \& Conti, A. (2008). Milk fat globule membrane components: a proteomic approach. Advances Experimental Medicine and Biology, 606, 129-141.

Choi, H.K., Willett, W.C., Stampfer, M.J., Rimm, E., \& Hu, F.B. (2005). Dairy consumption and risk of type 2 diabetes mellitus in men: A prospective study. Archives of Internal Medicine, 165(9), 997-1003.

Cicero, A., Gerocarni, B., Laghi, L., \& Borghi, C. (2011) . Blood pressure lowering effect of lactotripeptides assumed as functional foods: A meta-analysis of current available clinical trials. Journal of Human Hypertension, 25, 425-436.

Clare, D. A., Zheng, Z., Hassan, H.M., Swaisgood, H.E., \& Catignani, G.L. (2008). Antimicrobial properties of milk fat globule membrane fractions. Jornal of Food Protection, 71, 126-133.

Cohn, J.S., Kamili, A., Wat, E., Chung, R.W.S., \& Tandy, S. (2010). Dietary phospholipids and intestinal cholesterol absorption. Nutrients, 2, 116-127.

Contarini, G., \& Povolo M. (2013). Phospholipids in milk fat: Composition, biological and technological significance, and analytical strategies. International Journal of Molecular Sciences, $14,2808-2831$.

Conway, V., Couture, P., Richard, C., Gauthier, S., Pouliot, Y., \& Lamarche, B. (2013). Impact of buttermilk consumption on plasma lipids and surrogate markers of cholesterol homeostasis in men and women. Nutrition, Metabolism and Cardiovascular Diseases, 23, 1255-1262.

Conway, V., Gauthier, S.F., \& Pouliot, Y. (2010). Effect of cream pasteurization, microfiltration and enzymatic proteolysis on in vitro cholesterol- lowering activity of buttermilk solids. Dairy Science and Technology, 90, 449-460.

Corredig, M., \& Dalgleish, D.G. (1998b). Effect of heating of cream on the properties of milk fat globule membrane isolates. Journal of Agricultural and Food Chemistry, 46, 2533-2540.

Correding, M., Roesch, R.R., \& Dalgleish D.G. (2003). Production of a novel ingredient from buttermilk. Journal of Dairy Science, 86, 2744-2750. 
Costa, M.R., Elias-Argote, X.E., Jiménez-Flores, R., \& Gigante, M.L. (2010). Use of ultrafiltration and supercritical fluid extraction to obtain a whey buttermilk powder enriched in milk fat globule membrane phospholipids. International Dairy Journal, 20, 598-602.

Danielsen, E.M., \& Hansen, G.H. (2006). Lipid raft organization and function in brush borders of epithelial cells. Moleculer Membrane Biology, 23, 71-79.

Danthine, S., Blecker C., Paquot, Innocente, N., \& Deroanne, C. (2000). Évolution des connaissances sur la membrane du globule gras du lait: Synthèse bibliographique. Le Lait, 80, 209-222.

Demmer, E., Van Loan, M.D., Rivera, N., Rogers, T.S., Gertz, E.R., German, J.B., Smilowitz, J.T., \& Zivkovic, A.M. (2016). Addition of a dairy fraction rich in milk fat globule membrane to a high-saturated fat meal reduces the postprandial insulinaemic and inflammatory response in overweight and obese adults. Journal of Nutritional Science, 5, 1-11.

Dewettinck, K., Rombaut, R., Thienpont, N., \& Le, T.T. (2008). Nutritional and technological aspects of milk fat globule membrane material. International Dairy Journal, 18, 436-457.

Duan, R.D., \& Nilsson, A. (2009). Metabolism of sphingolipids in the gut and its relation to inflammation and cancer development. Progres in Lipid Research, 48, 62-72.

Evers, J.M. (2004). The milk fat globule membrane compositional and structural changes post secretion by the mammary secretory cell. International Dairy Journal, 14, 661-674.

El-Loly, M.M. (2011). Composition, properties and nutritional aspects of milk fat globule membrane -A review. Polish Journal of Food and Nutrition Sciences, 61, 7-32.

Farhang, B., Kakuda, Y., \& Corredig, M. ( 2012). Encapsulation of ascorbic acid in liposomes prepared with milk fat globule membrane-derived phospholipids. Dairy Science of Technology, 92, 353-366.

Fauquant, C., Briard- Bion,V. Leconte, N., Guichardant, M., \& Michalski, M.C. (2007). Membrane phospholipids and sterols in microfiltered milk fat globules. European Journal of Lipid Science and Technology, 109, 1167-1173.

Fong, B.Y., Norris, C.S., \& MacGibbon, A.K.H. (2007). Protein and lipid composition of bovine milk fat globule membrane. International Dairy Journal, 17, 275-288.

Fuller, K.L., Kuhlenschmidt, T.B., Kuhlenschmidt, M.S., Jiménez-Flores, R., \& Donovan, S.M. (2013). Milk fat globule membrane isolated from buttermilk or whey cream and their lipid components inhibit infectivity of rotavirus in vitro. Journal of Dairy Science, 96, 3488-3497.

Gallier, S., Gragson, D., Cabral, C., Jimenez-Flores, R., \& Everett, D.W. (2010a). Composition and fatty acid distribution of bovine milk phospholipids from processed milk products. Journal of Agricultural and Food Chemistry, 58, 10503-10511.

Gallier, S., Gragson, D., Jiménes- Flores, R., \& Everett, D. (2010b). Using confocal laser scanning microscopy to probe the milk fat globule membrane and associated proteins. Journal of Agricultural and Food Chemistry, 58, 4250-4257.

Gassi, J.Y., Famelart, M.H., \& Lopez, C. (2008). Heat treatment of cream affects the physicochemical properties of sweet buttermilk. Dairy Science Technology, 88, 369-385.

Graves, E.L.F., Beaulieu, A.D., \& Drackley, J.K. (2007). Factors affecting the concentration of sphingomyelin in bovine milk. Journal of Dairy Science, 90, 706-715. 
Govindasamy-Lucey, S., Lin, T., Jaeggi, J., Johnson, M., \& Lucey, J. (2006). Influence of condensed sweet cream buttermilk on the manufacture, yield, and functionality of pizza cheese. Journal of Dairy Science, 89, 454-467.

Guggisberg, D., Chollet, M., Schreier, K., Portmann, R., \& Egger, L. (2012). Effects of heat treatment of cream on the physical chemical properties of model oil-in-buttermilk emulsions. International Dairy Journal, 26, 88-93.

Gülseren, I., Guri, A., \& Corredig, M. (2012). Encapsulation of tea polyphenols in nanoliposomes prepared with milk phospholipids and their effect on the viability of HT-29 human carcinoma cells. Food Digestion, 3, 36-45.

Hamed, I. (2010). Utilization of buttermilk concentrate in the manufacture of functional processed cheese spread. Journal of American Science, 6, 876-882.

Heid, H.W., \& Keenan, T.W. (2005). Intracellular origin and secretion of milk fat globules. Europen Journal of Cell Biology, 84, 245-58.

Hellhammer, J., Waladkhani, A.R., Hero, T., \& Buss, C. (2010). Effects of milk phospholipid on memory and psychological stress response. British Food Journal, 112, 1124-1137.

Jensen, R.G., \& Newberg, D.S. (1995). Bovine milk lipids: Handbook of milk composition, Ed.: Jensen, R.G., San Diego, p: 543.

Jiménez-Flores, R., \& Brisson, G. (2008). The milk fat globule membrane as an ingredient: why, how, when? Dairy Science and Technology, 88, 5-18.

Kamili, A., Wat, E., Chung, R.W.S., Tandy, S., Weir, J.M., Meikle, P.J., \& Cohn, J.S. (2010). Hepatic accumulation of intestinal cholesterol is decreased and fecal cholesterol excretion is increased in mice fed a high-fat diet supplemented with milk phospholipids. Nutrition \& Metabolism, 7, 90101.

Karaman, S., \& Özcan, T. (2018) . Fonksiyonel süt ürünlerinin geliştirilmesinde nutrasötik bileşenler. Gıda ve Yem Bilimi-Teknolojisi, 20, 30-45.

Keenan, T.W. (2001). Milk lipid globules and their surrouding membrane: A brief history and perspectives for future research. Journal of mammary gland biology and neoplasia, 6, 365-371

Keenan, T.W., \& Dylewski D.P. (1995). Intracellular origin of milk lipid globules and the nature of structure of milk fat globule membrane: Advenced dairy chemistry lipits, vol. 2, Ed.: Fox, P.F., London, pp: 89.

Keenan, T.W., \& Mather, I.H. (2006). Intracellular origin of milk fat globules and the nature of the milk fat globul membrane: Advanced dairy chemistry. Ed.: Fox P.F., McSweeney, Paul, L.H. New York, NY, USA: Springer.

Kifah, S. D., Layla, A.A., \& Baha, N. A. (2014). Utilization of concentrated buttermilk in functional processed cheese manufacturing and studying some of its physicochemical properties. Journal of Nutrition, 13, 33-37.

Kuchta, A.M., Kelly, P.M., Stanton, C., \& Devery, R.A. (2012). Milk fat globule membrane-A source of polar lipids for colon health? A review. International Journal of Dairy Technolgy, 65, $315-333$

Kuchta-Noctor, A.M., Murray, B.A., Stanton, C., Devery, R., \& Kelly, P. M. (2016). Anticancer activity of buttermilk against SW480 colon cancer cells is associated with caspase-independent cell death and attenuation of Wnt, Akt, and ERK signaling. Nutrition and Cancer, 68, 1234-1246. 
Küllenberg, D., Taylor, L.A., Schneider, M., \& Massing, U. (2012). Health effects of dietary phospholipids. Lipids in Health and Disease, 11, 1-16.

Le, T.T., Van Camp, J., Pascual, P. A. L., Meesen, G., Thienpont, N., Messens, K., \& Dewettinck, K. (2011). Physical properties and microstructure of yoghurt enriched with milk fat globule membrane material. International Dairy Journal, 21, 798-805.

Lemonnier, L.A., Dillehay, D.L., Vespremi, M.J., Abrams, J., Brody, E., \& Schmelz, E.M. (2003). Sphingomyelin in the suppression of colon tumors: Prevention versus intervention. Archives of Biochemistry and Biophysics, 419, 129-138.

Lindholm, D., Wootz, H., \& Korhonen, L. (2006). ER stress and neurodegenerative diseases. Cell Death Differentiation, 13, 385-392.

Liutkevičius, A., Speičien, V., Alenčikienė, G., Mieželienė, A., Narkevičius, R., Kaminskas, A., Abaravičius, J. A., Vitkus, D., Jablonskienè, V., \& Sekmokienè, D. (2016). Fermented buttermilk-based beverage: impact on young volunteers' health parameters. Czech Journal of Food Sciences, 34, 143-148.

Logan, A., Auldist, M., Greenwood, J. \& Day. L. (2014). Natural variation of bovine milk fat globule size within a herd. Journal of Dairy Science, 97, 4072-4082.

Lopez, C. (2011). Milk fat globules enveloped by their biological membrane: Unique colloidal assemblies with a specific composition and structure. Current Opinion in Colloid \& Interface Science, 16, 391-404.

Lopez, C., Briard- Bion, V., Menard, O., Rousseau, F., Pradel, P., \& Besle, J.M. (2008). Phospholipid, sphingolipid, and fatty acid compositions of the milk fat globule membrane are modified by diet. Journal of Agricultural and Food Chemistry, 56, 5226-5236.

Lopez, C., Briard-Bion, V., Menard, O., Beaucher, E., Rousseau, F., Fauquant, J., Leconte, N., \& Robert, B. (2011). Fat globules selected from whole milk according to their size: different compositions and structure of the biomembrane, revealing sphingomyelin-rich domains. Food Chemistry, 125, 355-368.

Madenci, A.B., \& Bilgiçli, N. (2014). Effect of whey protein concentrate and buttermilk powders on rheological properties of dough and bread quality. Journal of Food Quality, 37, 117-124.

Månson, H.L. (2008). Fatty acids in bovine milk fat. Food \& Nutrition Research, 52, 1-3.

Martin, H.M., Hancock, J.T., Salisbury, V., \& Harrison, R. (2004). Role of xanthine oxidoreductase as an antimicrobial agent. Infection and Immunity, 72, 4933-4939.

Martinovic, A., Moe. K.M., Romeih, E., Aideh, B., Vogensen, F.K., Østlie, H., \& Skeie, S. (2013). Growth of adjunct Lactobacillus casei in Cheddar cheese differing in milk fat globule membrane components. International Dairy Journal, 31, 70-82.

Mather, I., \& Jack, L.J.W. (1996). A review of the molecular and cellular biology of butyrophilin, the major protein of bovine milk fat globule membrane. Journal of Dairy Science, 76, 38323850

Ménard, O., Ahmad, S., Rousseau, F., Briard- Bion, V., Gaucheron, F., \& Lopez, C. (2010). Buffalo vs. cow milk fat globules: Size distribution, zeta- potential, composition in total fatty acids and in polar lipids from the milk fat globule membrane. Food Chemistry, 120, 544-551.

Mesilati- Stahy, R., Mida, K., \& Argov- Argaman, N. (2011). Size- dependent lipit contet of bonive milk fat globule membrane phospholipids. Journal of Agricultural and Food Chemistry, 59, 7427 7435 . 
Michalski, M.C., Briard, V., \& Juaneda, P. (2005a). CLA profile in native fat globules of different sizes selected from raw milk. International Dairy Journal, 15, 1089-1094.

Michalski, M.C., Briard, V., Michel, F., Tasson, F., \& Poulain, P. (2005b). Size distribution of fat globules in human colostrum, breast milk, and infant formula. Journal of Dairy Science, 88, 19721940.

Moreno, O., Pastor, C., Muller, J., Atarés, L., González, C., \& Chiralt, A. (2014). Physical and bioactive properties of corn starch-Buttermilk edible films. Journal of Food Engineering, 141, 2736.

Morin, P., Pouliot, Y., \& Britten, M. (2008). Effect of buttermilk made from creams with different heat treatment histories on properties of rennet gels and model cheeses. Journal of Dairy Science, 91, 871-882.

Mudgil, D., \& Barak, S. (2016). Development of functional buttermilk by soluble fibre fortification. Agro Food Industry Hi Tech, 27, 44-47.

New, R. (1990). Preparation of liposomes: Liposomes-a practical approach, Ed: New, R., Oxford, p: 1 .

Nilsson, A., \& Duan, R.D. (2006). Absorption and lipoprotein transport of sphingomielin, Journal of Lipid Research, 47, 154-171.

Nagai, K. (2012). Bovine milk phospholipid fraction protects Neuro2a cells from endoplasmic reticulum stress via PKC activation and autophagy. Journal of Bioscience and Bioengineering, 114(4), 466-471.

Oshida, K., Shimizu, T., Takase, M., Tamura, Y., Shimizu, T., \& Yamashiro, Y. (2003). Effects of dietary sphingomyelin on central nervous system myelination in developing rats. Pediatric Research, 53(4), 589-593.

Parker, P. Sando, L., Kongsuwan, K., Tellam, L., \& Smith, S. (2010). Bovine Muc1 inhibits binding of enteric bacteria to Caco- 2 cell. Glycoconjugate Journal. 27, 89-97.

Pereira, M.A., Jacobs, D.R., Van Horn, L., Slattery, M.L., Kartashov, A.I., \& Ludwig, D.S. (2002). Dairy consumption, obesity, and the insulin resistance syndrome in young adults: The CARDIA study. JAMA, 287, 2081-2089.

Phipps, L.W. and Temple, D.M. 1982. Surface properties of milk fat globules: interfacial tension studies. Journal Dairy Research, 49, 61-72.

Roesch, R.R., Rincon, A., \& Corredig, M. (2004). Emulsifying properties of fractions prepared from commercial buttermilk by microfiltration. Journal of Dairy Science, 87, 4080-4087.

Romeih, E.A, Abdel-Hamid, M., \& Awad, A.A. (2014). The addition of buttermilk powder and transglutaminase improves textural and organoleptic properties of fat-free buffalo yogurt. Dairy Science and Technology, 94(3), 297-309.

Romeih,E.A., Moe, K.M., \& Skeie, S. (2012). The influence of fat globule membrane material on the microstructure of low-fat Cheddar cheese. International Dairy Journal, 26, 66-72.

Russell, A., Laubscher, A., Jimenez-Flores, R., \& Laiho, L.H. (2010). Investigating the protective properties of milk phospholipids against ultraviolet light exposure in a skin equivalent model. Proceedings of Spie, 7569, 75692Z-1- 75692Z-9. 
Saffon, M., Richard, V., Jiménez-flores, R., Gauthier, S. F., Britten, M., \& Pouliot, Y. (2013). Behavior of heat-denatured whey: buttermilk protein aggregates during the yogurt-making process and their influence on set-type yogurt properties. Foods, 2, 444-459.

Schubert, M., Contreras, C., Franz, N., \& Hellhammer, J. (2011). Milk-based phospholipids increase morning cortisol availability and improve memory in chronically stressed men. Nutrition Research, 31(6), 413-420.

Scott, L.L., Duncan, S.E., Sumner, S.S., \& Waterman, K.M. (2003a). Physical properties of cream reformulated with fractionated milk fat and milk-derived components. Journal of Dairy Science, 86, 3395-3404.

Shaikh, M.F. B., \& Rathi, S. D. (2009). Utilisation of buttermilk for the preparation of carbonated fruit-flavoured beverages. International Journal of Dairy Technology, 62, 564-570.

Shimizu, M., Yamauchi, K., \& Kanno, C. (1980). Effect ofproteolytic digestion of milk fat globule membrane proteins on stability of the globules. Milchwissenschaft, 35, 9-12.

Singer, S.J., \& Nicolson, G.L. (1972). The fluid mosaic model of the structure of cell membranes. Science, 175, 720- 731 .

Singh, H. (2006). The milk fat globule membrane-A biophysical system for food applications. Current Opinion in Colloid \& Interface Science, 11, 154-163.

Skeie, S., Alseth, G., Østlie, H., Abrahamsen, R., Johansen, A., \& Øyaas, J. (2013). Improvement of the quality of low-fat cheese using a two-step strategy. International Dairy Journal, 33, 153-162.

Skryplonek, K ., Dmytrów, I., \& Mituniewicz-Małek, A. (2019). International Journal of Dairy Technology, 3, 71-459.

Snow, D. R., Jimenez- Flores, R., Ward, R.E., Cambell, J., Young, M.J., Nemere, I., \& Hintze, K.J. (2010). Dietary milk fat globule membrane reduces the incidence of aberrant crypt foci in Fischer-344 rats. Journal of Agricultural and Food Chemistry, 58, 2157-2163.

Snow, D., Ward, R.E., Olsen, A., Jimenez- Flores, R., \& Hintze, K.J. (2011). Membranerich milk fat diet provides protection against gastrointestinal leakiness in mice treated with lipopolysaccharide. Journal of Dairy Science, 94, 2201-2212.

Sodini, I., Morin, P., Olabi, A., \& Jiménez-Flores, R. (2006). Compositional and functional properties of buttermilk: a comparison between sweet, sour, and whey buttermilk. Journal of Dairy Science, 89, 525-536.

Spitsberg, V. (2005). Invited review: bovine milk fat globule membrane as a potential nutraceutical. Journal of Dairy Science, 88, 2289-2294.

Tanaka, K., Hosozawa, M., Kudo, N., Yoshikawa, N., Hisata, K., Shoji, H., Shinohara, K., \& Shimizu, T. (2012). The pilot study: Sphingomyelin-fortified milk has a positive association with the neurobehavioural development of very low birth weight infants during infancy, randomized control trial. Brain \& Development, 35(1), 45-52.

Timby, N., Hernell, O., Vaarala, O., Melin, M., Lönnerdal, B., \& Domellöf, M. (2015). Infections in infants fed formula supplemented with bovine milk fat globule membranes. Journal of Pediatric Gastroenterology Nutrition, 60, 384-389.

Turcot,S., St-Gelais, D., \& Turgeon, S.L. (2002). Affinage de fromages allégés de type cheddar fabriqués à partir de laits enrichis en phospholipides. Lait, 82, 209-223. 
Truong, T., Palmer, M., Bansal, N., \& Bhandari, B. (2016). Effect of milk fat globule size on the physical functionality of dairy products, SpringerBriefs in Food, Health, and Nutrition, $70 \mathrm{p}$.

Vanderghem, C., Bodson P., Danthine, S., Paquot M., Deroanne C., \& Blecker C. (2010). Milk fat globule membrane and buttermilk: From composition to valorization. Biotechnology, Agronomy, Society and Environment, 14(3), 485-500.

Veereman-Wauters, G., Staelens, S., Rombaut, R., Dewettinck, K., Deboutte, D., Brummer, R.J., Boone, M., \& Le Ruyet, P. (2012). Milk fat globule membrane (INPULSE) enriched formula milk decreases febrile episodes and may improve behavioral regulation in young children. Nutrition, $28,749-752$.

Vesper, H., Schmelz, E.M., Nikolova-Karakashian, M.N., Dillehay, D.L., Lynch, D.V., \& Merrill, A.H. (1999). Sphingolipids in food and the emerging importance of sphingolipids to nutrition. The Journal of Nutrition, 129, 1239-1250.

Walstra, P. (1995). Physical chemistry of milk fat globules: Advanced dairy chemistry, Lipids, vol. 2, Chapman \& Hall, Ed.: Fox, P. D., London, pp: 101.

Wang, X., Hirmo, S., Willen, R., \& Wadström, T. (2001). Inhibition of Helicobacter pylori infection by bovine milk glycoconjugates in a BA1b/cA mouse model. Journal of Medical Microbiology, $50,430-435$.

Wat, E., Tandy, S., Kaper, E., Kamili, A., Chung, R.W.S., Brown, A., Rowney, M., \& Cohn J.S. (2009). Dietary phospholipid-rich dairy milk extract reduces hepatomegaly, hepatic steatosis and hyperlipidemia in mice fed a high-fat diet. Atherosclerosis, 205, 144-150.

Ye, A., Singh, H., Taylor, M.W., \& Anema S. (2002). Characterization of protein components of natural and heat-treated milk fat globule membranes. International Dairy Journal, 12, 393-402.

Zanabria, R., Tellez, A.M., Griffiths, M., \& Corredig, M. (2013). Milk fat globule membrane isolate induces apoptosis in HT- 29 human colon cancer cells. Food \& Function, 4, 222-230.

Zanabria, R., Tellez, A.M., Griffiths, M., Sharif, S., \& Corredig, M. (2014a). Modulation of immune function by milk fat globule membrane isolates. Journal of Dairy Science, 97, 20172026.

Zanabria, R., Tellez, A.M., Griffiths, M.W., \& Corredig, M. (2014b). The antiproliferative properties of the milk fat globule membrane are affected by extensive heating. Dairy Science of Technology, 94, 439- 453. 